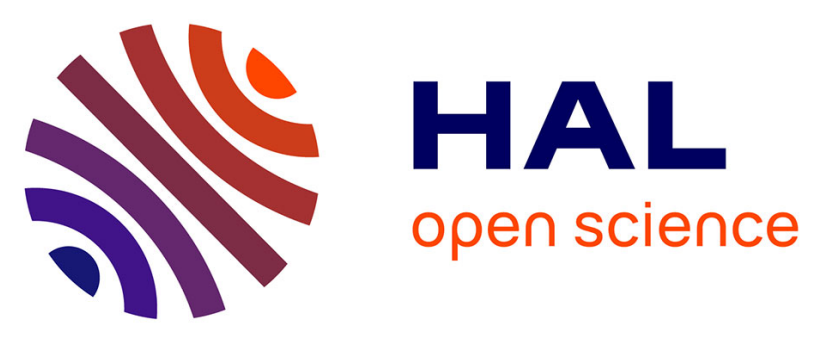

\title{
Discussion on 'Palaeoseismic structures in Quaternary sediments, related to an assumed fault zone north of the Permian Peissen-Gnutz salt structure (NW Germany) - Neotectonic activity and earthquakes from the Saalian to the Holocene' (Grube, 2019)
}

Pascal Bertran, Kevin Manchuel, Deborah Sicilia

\section{To cite this version:}

Pascal Bertran, Kevin Manchuel, Deborah Sicilia. Discussion on 'Palaeoseismic structures in Quaternary sediments, related to an assumed fault zone north of the Permian Peissen-Gnutz salt structure (NW Germany) - Neotectonic activity and earthquakes from the Saalian to the Holocene' (Grube, 2019). Geomorphology, 2020, 365, pp.106704. 10.1016/j.geomorph.2019.03.010 . hal-03136518

\author{
HAL Id: hal-03136518 \\ https://hal.science/hal-03136518
}

Submitted on 9 Feb 2021

HAL is a multi-disciplinary open access archive for the deposit and dissemination of scientific research documents, whether they are published or not. The documents may come from teaching and research institutions in France or abroad, or from public or private research centers.
L'archive ouverte pluridisciplinaire HAL, est destinée au dépôt et à la diffusion de documents scientifiques de niveau recherche, publiés ou non, émanant des établissements d'enseignement et de recherche français ou étrangers, des laboratoires publics ou privés. 
Geomorphology

Manuscript Number: GEOMOR-8414R1

Title: Discussion on 'Palaeoseismic structures in Quaternary sediments, related to an assumed fault zone north of the Permian Peissen-Gnutz salt structure (NW Germany) - Neotectonic activity and earthquakes from the Saalian to the Holocene' (Grube, 2019)

Article Type: Reply

Keywords: Palaeoseismology; Permafrost; Brittle deformation

Corresponding Author: Dr. Pascal Bertran, PhD

Corresponding Author's Institution: INRAP / PACEA

First Author: Pascal Bertran, PhD

Order of Authors: Pascal Bertran, PhD; Kevin Manchuel, Ph.D.; Deborah Sicilia, Ph.D.

Abstract: We discuss the significance of deformation structures in Quaternary sediments observed by Grube (2019) in the Peissen quarries (NW Germany) in light of the geological context. Evidence for polygonal patterns visible in aerial images in the study area shows that the wedge structures interpreted by Grube (2019) as earthquake-induced sand blows may rather correspond to thermal contraction cracks filled with aeolian sand in a permafrost environment. In the study sites, brittle deformations caused by (i) the rise of a salt diapir, (ii) salt dissolution, (iii) the development of Pleistocene permafrost and (iv) possibly, water circulation under pressure in the Scandinavian ice sheet margin may have coexisted. We support the idea that, while the morphology of deformation generally makes it possible to determine the stress state to which the sediments have been subjected and the quantity of water available in the system at the time of deformation, the nature of the factors causing the stresses remains difficult to identify. In the end, we highlight other useful criteria that should be privileged for palaeoseismic research in such complex geological settings. 
1 Discussion on 'Palaeoseismic structures in Quaternary sediments, related to an assumed

2 fault zone north of the Permian Peissen-Gnutz salt structure (NW Germany) - Neotectonic

3 activity and earthquakes from the Saalian to the Holocene' (Grube, 2019)

4

5

6

7

8

9

10

Pascal Bertran $^{1 *}$, Kevin Manchuel $^{2}$, Deborah Sicilia ${ }^{2}$

${ }^{1}$ Inrap / PACEA, bâtiment B2, allée Geoffroy-Saint-Hilaire, 33615 Pessac, France

${ }^{2}$ EDF, TEGG/Service Géologique Géotechnique, 905 Avenue du Camp de Menthe, 13097 Aix-en-

Provence, France

* Corresponding author. Email address: pascal.bertran@inrap.fr

\section{Abstract}

We discuss the significance of deformation structures in Quaternary sediments observed by Grube (2019) in the Peissen quarries (NW Germany) in light of the geological context. Evidence for polygonal patterns visible in aerial images in the study area shows that the wedge structures interpreted by Grube (2019) as earthquake-induced sand blows may rather correspond to thermal contraction cracks filled with aeolian sand in a permafrost environment. In the study sites, brittle deformations caused by (i) the rise of a salt diapir, (ii) salt dissolution, (iii) the development of Pleistocene permafrost and (iv) possibly, water circulation under pressure in the Scandinavian ice sheet margin may have coexisted. We support the idea that, while the morphology of deformation generally makes it possible to determine the stress state to which the sediments have been subjected and the quantity of water available in the system at the time of deformation, the nature of the factors causing the stresses remains difficult to identify. In the end, we highlight other useful criteria that should be privileged for palaeoseismic research in such complex geological settings.

Keywords: Palaeoseismology; Permafrost; Brittle deformation

\section{Introduction}

Grube's (2019) article on brittle and ductile deformations affecting Quaternary sediments in the Peissen region (northwest Germany) provides interesting data on potential traces of palaeoearthquakes and is part of a recent effort to extend seismicity catalogues in Europe beyond the period for which instrumental data and historical texts are available. These deformation 
structures complement the many other structures already described in northern Europe, particularly by Hoffmann and Reicherter (2012), Brandes and Winsemann (2013), van Loon and Pisarska-Jamrozy (2014) and van Loon et al. (2016), which were also interpreted as earthquake-induced. However, the geographical proximity of all these structures does not constitute proof of a common origin. The main reasons for this relate to the complex local geomorphological context, marked by (1) the development of permafrost during the last glaciation, (2) the proximity of the Scandinavian ice sheet during the last Glacial Maximum, and (3) the presence of a salt diapir in the immediate vicinity of the study sites. These aspects will be developed in detail here. The outcome of this analysis is that, while the morphology of deformation generally makes it possible to determine the stress state to which the sediments have been subjected and the quantity of water available in the system at the time of deformation, the nature of the factors causing the stresses remains difficult to identify. Laboratory experiments and field observations indicate that similar brittle and/or ductile deformations may occur in relation to various geomorphological processes. Therefore, the multiplicity of potential factors that may have been involved in the sector studied by Grube (2019) does not make it possible to determine confidently the origin of the deformation structures.

\section{Sand blows and sand wedges in a permafrost context}

The wedge-shaped structures filled with sand described by Grube (2019) and interpreted as sand blows due to ground fluidization caused by seismic shaking are very similar to the wedges caused by thermal contraction of the ground in periglacial environments and filled with aeolian sand (sand wedges) or a mixture of sand and ice (composite wedge pseudomorphs) (e.g., Murton, 2013; Andrieux et al., 2016a, b). These wedges have a $V$ shape, sand veins extending from the base (apophyses), a depth (up to $1.7 \mathrm{~m}$ ) and an internal organization typical of periglacial structures. Vertical lamination is preserved in one of the wedges illustrated in Fig. 11e of Grube (2019). The lamination, common in thermal contraction wedges, is related to repeated cracking of the ground during winters and the infiltration of aeolian sand into the crack (Fig. 1). When the filling is composed of sand and ice (composite wedges), melting of ice causes the lamination to vanish and the wedge to deform. Coarser material from the host sediment can fill the depression. Ghysels and Heyse (2006) and Buylaert et al (2009) have described similar examples in Belgium OSL-dated to the Weichselien and Saalien. Creep of fine-grained host material during melting or repeated thaw cycles can also lead to the formation of globular structures comparable to those shown in Grube's (2019) Fig. 11b (Fig. 1D).

One of the most relevant criteria for discriminating these structures from sand blows is their organization into large polygons, which reach 10 to $30 \mathrm{~m}$ in diameter. Unfortunately, Grube (2019) 
has not documented this aspect. However, some data indicate that the presence of sand wedges or composite wedge pseudomorphs is highly probable in the study area. These data are (1) polygons visible on satellite photographs accessible in Google Earth; one of the identified sites is located in the immediate vicinity of Pit 3, another of Pit 2 (Fig. 2); (2) the mention by Christensen (1978) of abundant fossil thermal contraction polygons visible in aerial photographs in Denmark and northern Germany; the geo-referencing of Christensen's map shows that the study sites are located in an area where more than $5 \%$ of agricultural land is affected by polygons; and (3) the concomitance of continuous permafrost during the last glaciation (Vandenberghe et al., 2014) and coversand deposition (Kasse, 1997; Zeeberg, 1998), which is a pattern highly favourable to the formation of sand wedges over large surfaces. Therefore, the interpretation of these structures as periglacial sand wedges rather than seismogenic sand blows seems most likely in the current state of the analysis and a seismic origin cannot therefore be retained without more supporting evidence.

\section{Brittle deformation}

Unconsolidated and well-drained sediments under stress deform in a brittle manner. The stress can be caused by wide range of geological processes. Many experiments using analog models under stress have been described in the literature. These models use cohesionless granular materials, most often sand, sometimes interlayered with ductile levels (cohesive wet clays, or purely viscous silicone paste). The results constitute a data set that can be used to understand the brittle deformation of non-lithified Quaternary sediments.

Experiments by Komuro (1987) and Walter and Troll (2001) reproduced the growth of a lenticular body (a putty ball or an inflated chamber) under a granular cover. The increase in volume leads to the formation of a dome and the development of subvertical radial cracks at the top (Fig. 3A,B). As the dome grows, cracks are formed that cut at right angles the radial cracks and are arranged in a more or less concentric pattern. At the top of the dome, the blocks bounded by the cracks collapse, leading to the formation of a polygonal central depression limited by normal faults. Walter and Troll (2001) reproduced the succession of growth phases followed by collapse of the cover. The interaction between the fractures created during swelling and those related to collapse generates blocks of variable size and a high degree of material fragmentation (Fig. 3F).

This type of structure accurately reflects the fracturing of the sediment or peat layer that covers intrusive ice mounds (pingos, frost blisters) or segregated ice mounds (lithalsas) in a periglacial context. Examples have been described in the Canadian Arctic by Mackay $(1988,1998)$ and Pollard (1991) (Fig. 4A). Davison et al. (2000) and Marco et al. (2002) also observed a system of radial and tangential cracks in the sedimentary cover at the periphery of salt diapirs (Fig. 4B). In the example 
detailed by Marco et al. (2002), many structures correspond to clastic dykes and probably result from the filling of cracks opened from the surface, which were formed in connection with the rise of the diapir.

Experiments that reproduce the rise of a block of substratum, and those that simulate the collapse of an unconsolidated cover over a cavity, provide comparable results. In both cases, the faults are concentrated to a limited area at the edge of the raised block or the cavity. Sanford's (1959) experiments consisted in lifting a rigid block limited by vertical edges under a cover of sand or sand and clay. Reverse curved faults propagate towards the surface and the subsided area (Fig. 3C). As pointed out by Sanford (1959), the reverse faults, which are subvertical at the base and evolve into thrusts towards the surface, are not related to horizontal compression in the model, but to vertical movements at depth. Similar results were also obtained in a series of experiments designed to reproduce the roof collapse over a cavity (Roche et al., 2001; Walter and Troll, 2001; Geyer et al., 2006; Coumans and Stix, 2016). In these experiments, bell-shaped reverse fractures form above the cavity together with annular extension fractures starting from the surface at the periphery. Progressive roof collapse occurs in connection with the propagation of the bell-shaped fractures up to the surface (Fig. 3D,E). Coumans and Stix (2016) reproduced the situation in which the thickness of the cover is not homogeneous. In this case, subsidence associated with reverse faulting occurs where the sediment thickness above the cavity is lowest, whereas normal faults develops at the opposite side (Fig. 3G). The final depression has an asymmetrical shape.

Many examples of curved reverse faults and associated normal faults have been described in natural environments. They comprise the cover of salt diapirs undergoing dissolution (Simon and Soriano, 1986; Davison et al., 1996) (Fig. 4B), sediments affected by the collapse of a karstic cavity (Soriano et al., 2012; Simon et al., 2014; Luzón et al., 2012) (Fig. 4E), subglacial deposits (eskers) deformed by glacier melt-out (McDonald and Shilts, 1975), and lahars or fluvioglacial deposits (jökulhlaup) deformed by melting of ice-blocks (Branney and Gilbert, 1995; Fay, 2000). Calmels et al. (2008) identified reverse ice-filled faults dipping 50 to $90^{\circ}$ in a segregated ice mound (lithalsa) in northern Quebec. According to Calmels et al. (2008), these faults formed during the growth of ice lenses during permafrost build-up. Reverse faults have also been identified in ramparts created by the melting of Pleistocene ice mounds (Payette and Séguin, 1979; Kasse and Bohncke, 1992; Pissart, 2000; Bertran et al., 2018) and in thermokarst lake deposits (Murton, 1996; Bertran et al., 2018) (Fig. $4 C)$.

Other experiments have reproduced deformations created by shortening (Bonini et al., 2000; Bonini, 2007). In these models, detachment occurs at the substratum - cover interface and reverse faults 
with low dip (thrusts) form in the cover to accommodate the shortening (Fig. 3E). Thrusting leads to the formation of an anticline at the top of the ramp and conjugate reverse faults delimiting pop-up structures develop. The frontal bulge can collapse along normal faults that form as shortening and bulging progress.

This type of deformation is typically observed in the frontal bulge of landslides (Coombs and Norris, 1981; McCalpin and Thakkar, 2003) (Fig. 4D) and at the front of emerging deep-seated reverse faults (Philip et al., 1992; McCalpin and Thakkar, 2003).

In summary, the available models show that it is possible to identify the stress state that caused brittle deformation from the fracture geometry. However, the factors underlying stress remain more difficult to determine and observations in natural environments indicate that many geological processes are able to generate similar deformations. Comparable conclusions were also drawn for soft-sediment deformations (e.g., Moretti et al., 2016). Analysis of the fracture pattern can provide insight into the factors that may be involved. However, the usually limited extent (i.e., a few tens of metres) of the outcrops is one of the main limitations for documenting accurately the general fracture pattern. An exception is fracturing due to thermal contraction of the ground in a periglacial context, where the growth of ice or sand wedges generates easily identifiable polygonal patterns.

The site studied by Grube (2019) is located in a complex geological environment, where deformations created by the rise of a salt diapir, salt dissolution, the development of Pleistocene permafrost and possibly, by water circulation under pressure in the Scandinavian ice sheet margin (see Boulton et al., 1993; Murton, 2005; Ravier et al., 2015) have overlapped. Consequently, this site seems unfavourable to the detection of palaeoearthquakes, insofar as the structures observed at the scale of the outcrops do not allow the factors potentially involved to be discriminated against. The association of normal and reverse faults (Fig. 12 of Grube (2019)) may well reflect the deformation associated with the rise and dissolution of the underlying salt diapir, or that created by the growth and melting of ice bodies during the Weichselian, rather than earthquake-induced processes. Diapir uplift caused by loading of the surrounding land by the Weichselian ice sheet likely occurred as demonstrated by Lang et al. (2014).

\section{Conclusion and prospects}

The arguments proposed by Grube (2019) for a seismic origin of the structures observed in the Peissen quarries are not convincing when considering the context. In such geological settings, the types of criteria that should be favoured in palaeoseismic research are (1) surface lineation identifiable by the relief or an offset in geological structures, which may reflect the emergence of deep-seated faults (although possibly non-seismogenic), and (2) fractured pebbles associated with a 
fault or in the associated damage zone, which provide evidence for the seismogenic nature of the fault.

The first criterion is traditionally used in palaeoseismology (e.g., Chardon et al., 2005; Camelbeeck et al., 2007; Baize et al., 2019) and serves as a guide for trenching to study the fault's history. This approach ensures that the structures analysed in cross-section are effectively related to a deepseated fault. The persistence of relief, however, implies that the fault has been active recently.

Pebble fracturing along seismogenic faults is attested by some authors, particularly Kübler et al (2018), in settings where the lithostatic stress is null (subsurface). Fragmentation results from the development of stress higher than pebble strength (especially in the case of poorly resistant lithologies such as argillites or sandstones) caused by shearing along the fault. This stress remains significantly lower than that required for quartz grain cataclasis (typically in deep fault gouges, e.g., Cashman and Cashman, 2000; Torabi et al., 2007; Mair and Abe, 2008; Kristensen et al., 2013) and requires the pebbles to be in contact with each other (clast-supported material). According to Radjai et al. (1998), the stress transmitted along the load-bearing network is much higher than the average vertical stress, allowing pressures higher than pebble strength to develop during shear. Seismic compression waves and waves released by the bursting of neighbouring pebbles are likely to be involved in fracturing (Davies et al., 2012), as long as fracturing is not observed along nonseismogenic faults.

Cataclasis could thus provide a reliable indicator that can be used in palaeoseismological analysis, particularly when it affects many pebbles in the damage zone around a fault (Fig. 5A, B). Other factors that can cause fracturing of subsurface pebbles include gelifraction (Matsuoka, 2001, 2008; Jia et al., 2017) and mass flow of debris. Gelifraction is caused by crack expansion resulting from ice growth in fissured rocks and segregation ice growth due to water migration in weak and highly porous rocks such as chalk. Gelifraction is a common feature in cold environments and mainly affects limestones, shales and all kinds of fractured rocks (Fig. 5C, D). It remains ineffective on compact rocks such as most alluvial pebbles, for which the impacts caused by the fluvial transport have eliminated the least resistant and most fissured parts. Fractured pebbles are actually rare (but not totally absent) in Quaternary alluvial deposits and are scattered throughout the deposits. Cataclasis typifies the sedimentary flows involving a large volume of debris, i.e., rock avalanches (Siebert, 1984; Yarnold, 1993; Bertran, 2003). It develops within the whole flow and does not concentrate along identifiable faults. It gives rise to so-called "jigsaw" structures (Fig. 5E, F). In smaller flows (debris flows, snow avalanches), flaking of the transported blocks dominates. In most cases, 
sedimentological criteria and the non-localized nature of cataclasis make it possible to identify the factor involved.

Fractured pebbles associated with faults and embedded in unconsolidated or weakly cemented fluvial deposits were mentioned by several authors (Jorda, 1982; Carbon et al., 1993; Baize et al., 2002; Guignard et al., 2005) in southeastern France, the most seismic region of the country during historical times, and provide reliable indices for palaeo-earthquakes. To our knowledge, similar such structures have not been reported in areas further north and should focus research.

\section{Acknowledgements}

We acknowledge O. Bellier for showing us sites with fractured pebbles in SE France. The funds have been provided by Electricité de France (EDF) and Institut de Recherches en Archéologie Préventive (Inrap) through the SISMOGEL project. M. Moretti and an anonymous reviewer are also thanked for their constructive remarks on the manuscript.

\section{References}

Andrieux, E., Bertran, P., Saito, K., 2016a. Spatial analysis of the French Pleistocene permafrost by a GIS database. Permafrost and Periglacial Processes 27, 17-30.

Andrieux, E., Bertran, P., Antoine, P., Deschodt, L., Lenoble, A., Coutard, S., 2016b. Database of pleistocene periglacial features in France: description of the online version. Quaternaire 27, 329-339.

Baize, S., Cushing, M., Lemeille, F., Granier, T., Grellet, B., Carbon, D., Combes, P., Hibsch, C., 2002. Inventaire des indices de rupture affectant le Quaternaire, en relation avec les grandes structures connues, en France métropolitaine et dans les régions limitrophes. Mémoires de la Société Géologique de France, Nouvelle Série, 175, 141 p.

Baize, S., Reicherter, K., Avagyan, A., Belyashov, A., Pestov, E., Vittori, E., Arakelyan, A., Decker, K., 2019. First assessment of recent tectonics and paleoearthquakes along the Irtysh fault (eastern Kazakhstan). Geomorphology 326, 90-106.

Ballard, J.F., Brun, J.P., Van den Driessche, J., Allemand, P., 1987. Propagation des chevauchements au-dessus des zones de décollement : modèles expérimentaux. Courrier de l'Académie des Sciences de Paris 305, série II, 1249-1253. 
Bertran, P., 2003. The rock-avalanche of February 1995 at Claix (French Alps). Geomorphology 54, 339-346.

Bertran, P., Andrieux, E., Bateman, M., Font, M., Manchuel, K., Sicilia, D., 2018. Features caused by ground ice growth and decay in Late Pleistocene fluvial deposits, Paris Basin, France. Geomorphology 310, 84-101.

Bonini, M., 2007. Deformation patterns and structural vergence in brittle-ductile thrust wedges: An additional analogue modelling perspective. Journal of Structural Geology 29, 141-158.

Bonini, M., Sokoutis, D., Mulutega, G., Katrivano,s E., 2000. Modelling hanging wall accomodation above rigid thrust ramps. Journal of Structural Geology 22, 1165-1179.

Boulton, G.S., Slot, T., Blessing, K., Glasbergen, P., Leijnse, T., van Gijssel, K., 1993. Deep circulation of groundwater in overpressured subglacial aquifers and its geological consequences. Quaternary Science Reviews 12, 739-745.

Brandes, C., Winsemann, J., 2013. Soft-sediment deformation structures in NW Germany caused by Late Pleistocene seismicity. International Journal of Earth Sciences 102, 2255-2274.

Branney, M.J., Gilbert, J.S., 1995. Ice-melt collapse pits and associated features in the 1991 lahar deposits of Volcan Hudson, Chile: criteria to distinguish eruption-induced glacier melt. Bulletin of Volcanology 57, 293-302.

Buylaert, J.P., Ghysels, G., Murray, A.S., Thomsen, K.J., Vandenberghe, D., De Corte, F., Heyse, I., Van den Haute, P., 2009. Optical dating of relict sand wedges and composite-wedge pseudomorphs in Flanders, Belgium. Boreas 38, 160-175.

Calmels, F., Allard, M., Delisle, G., 2008. Development and decay of a lithalsa in Northern Quebec: a geomorphological history. Geomorphology 97, 287-299.

Camelbeeck, T., Vanneste, K., Alexandre, P., Verbeeck, K., Petermans, T., Rosset, P., Everaerts, M., Warnant, R., Van Camp, M., 2007. Relevance of active faulting and seismicity studies to assessments of long-term earthquake activity and maximum magnitude in intraplate northwest Europe, between the Lower Rhine Embayment and the North Sea. In: Stein, S., Mazzotti, S. (ed.), Continental Intraplate Earthquakes: Science, Hazard, and Policy Issues. The Geological Society of America Special Paper 425, pp. 193-223.

Carbon, D., Combes, P., Cushing, M., Granier, T., 1993. Enregistrement d'un paléoséisme dans des sédiments du pléistocène supérieur dans la vallée du Rhône : quantification de la déformation. Géologie Alpine 69, 33-48. 
Cashman, S., Cashman, K., 2000. Cataclasis and deformation-band formation in unconsolidated marine terrace sand, Humbolt County, California. Geology 28, 111-114.

Chardon, D., Hermitte, D., Nguyen, F., Bellier, O., 2005. First paleoseismological constraints on the strongest earthquake in France (Provence) in the twentieth century. Geology 33, 901- 904.

Coombs, D.S., Norris, R.J., 1981. The east Abbotsford, Dunedin, New Zealand, landslide of august 8, 1979, an interim report. Bulletin de Liaison des Ponts-et-Chaussées, nº spécial X, 27-34.

Coumans, J.P., Stix, J., 2016. Caldera collapse at near-ridge seamounts: an experimental investigation. Bulletin of Volcanology 78, 70, doi 10.1007/s00445-016-1065-9.

Christensen, L., 1978. Waterstress conditions in cereals used in recognizing fossil ice-wedge polygonal patterns in Denmark and northern Germany. Proceedings of the Third International Conference on Permafrost, National research Council of Canada, Edmonton, Canada, vol. 1, pp. 254261.

Davison, I., Bosence, D., Alsop, G.I., Al-Aawah, M.H., 1996. Deformation and sedimentation around active Miocene salt diapirs on the Tihama Plain, northwest Yemen. In: Alsop, G.L., Blundell, D.J., Davison, I. (eds.), Salt tectonics. Geological Society, London, Special Publication 100, pp. 23-39. Davison, I., Alsop, G.I., Evans, N.G., Safaricz, M., 2000. Overburden deformation patterns and mechanisms of salt diaper penetration in the Central Graben, North Sea. Marine and Petroleum Geology 17, 601-618.

Davies, T.R.H., McSaveney, M.J., Boulton, C.J., 2012. Elastic strain energy release from fragmenting grains: effects on fault rupture. Journal of Structural Geology 38, 265-277.

Fay, H., 2000. Formation of kettle holes following a glacial outburst flood (jökulhlaup), Skeidararsandur, southern Iceland. IAHS Publ. 271, 205-210.

Geyer, A., Folch, A., Marti, J., 2006. Relationship between caldera collapse and magma chamber withdrawal: an experimental approach. Journal of Volcanology and Geothermal Research 157, 375386.

Guignard, P., Bellier, O., Chardon, D., 2005. Géométrie et cinématique post-oligocène des failles d’Aix et de la moyenne Durance (Provence, France). Comptes-Rendus Géoscience 337, 375-384.

Guysels, G., Heyse, I., 2006. Composite-wedge pseudomorphs in Flanders, Belgium. Permafrost and Periglacial Processes 17, 145-161. 
Hoffmann, G., Reicherter, K., 2012. Soft-sediment deformation of Late Pleistocene sediments along the southwestern coast of the Baltic Sea (NE Germany). International Journal of Earth Sciences 101, 351-363.

Jia, H., Leith, K., Krautblatter, M., 2017. Path-dependent frost-wedging experiments in fractured, lowpermeability granite. Permafrost and Periglacial Processes 28, 698-709. Jorda, M., 1992. La tectonique plio-quaternaire des Préalpes de Digne et ses prolongements récents. L'enseignement des hautes nappes alluviales. In: Le Villafranchien méditerranéen, Université des Sciences et Techniques de Lille, 1982, 425-440.

Kasse, C., 1997. Cold-climate Aeolian Sand-sheet formation in North-Western Europe (c. 14-12.4 ka); a response to permafrost degradation and increased Aridity. Permafrost and Periglacial Processes 8 , 295-311.

Kasse, K., Bohncke, S., 1992. Weichselian Upper Pleniglacial aeolian and ice-cored morphology in the southern Netherlands (Noort-Brabant, Groote Peel). Permafrost and Periglacial Processes 3, 327342.

Komuro, H., 1987. Experiments on cauldron formation: a polygonal cauldron and ring fractures. Journal of Volcanology and Geothermal Research 31, 139-149.

Kübler, S., Friedrich, A.M., Gold, R.D., Strecker, M.R., 2018. Historical coseismic surface deformation of fluvial gravel deposits, Schafberg fault, Lower Rhine Graben, Germany. International Journal of Earth Science 107, 571-585.

Kristensen, M.B., Child, C., Olesen, N.Ø., Korstgård, J.A., 2013. The microstructure and internal architecture of shear bands in sand-clay sequences. Journal of Structural Geology 46, 129-141. Lang, J., Hampel, A., Brandes, C., Winsemann, J., 2014. Response of salt structures to ice loading: implications for ice-marginal and subglacial processes. Quaternary Science Reviews 101, 217-233. Luzón, A., Rodriguez-López, J.P., Pérez, A., Soriano, M.A., Gil, H., Pocovi, A., 2012. Karst subsidence as a control on the accumulation and preservation of aeolian deposits: A Pleistocene example from a proglacial outwash setting, Ebro Basin, Spain. Sedimentology 59, 2199-2225. Sciences 25, 495-511. Mackay, J.R., 1998. Pingo growth and collapse, Tuktoyaktuk Peninsula area, western Arctic coast, Canada: A long-term field study. Géographie Physique et Quaternaire 52, 271-323. 
Mair, K., Abe, S., 2008. 3D numerical simulations of fault gouge evolution during shear: Grain size reduction and strain localization. Earth and Planetary Science Letters 274, 72-81.

Marco, S., Weinberger, R., Agnon, A., 2002. Radial clastic dykes formed by a salt diapir in the Dead Sea Rift, Israel. Terra Nova 14, 288-294.

Matsuoka, N., 2001. Microgelivation versus macrogelivation: towards bridging the gap between laboratory and field frost weathering. Permafrost and Periglacial Processes 12, 299-313.

Matsuoka, N., 2008. Frost weathering and rockwall erosion in the southeastern Swiss Alps: Long-term (1994-2006) observations. Geomorphology 99, 353-368.

McCalpin, J.P., Thakkar, M.G., 2003. 2001 Bhuj-Kachchh earthquake: surface faulting and its relation with neotectonics and regional structures, Gujarat, Western India. Annals of Geophysics 46, 937-956. McDonald, B.C., Shilts, W.W., 1975. Interpretation of faults in glaciofluvial sediments. In: Jopling, A.V., McDonald, B.C. (eds.), Glaciofluvial and glaciolacustrine sedimentation. Society of Economic Paleontologists and Mineralogists, Tulsa, USA, Special Publication 23, pp. 123-131.

Moretti, M., Alfaro, P., Owen, G., 2016. The environmental significance of soft-sediment deformation structures: key signatures for sedimentary and tectonic processes. Sedimentary Geology 344, 1-4.

Murton, J.B., 1996. Thermokarst-lake-basin sediments, Tuktoyaktuk Coastlands, western arctic Canada. Sedimentology 43, 737-760.

Murton, J.B., 2005. Ground-ice stratigraphy and formation at North Head, Tuktoyaktuk Coastlands, Western Arctic Canada: a product of glacier-permafrost interactions. Permafrost and Periglacial Processes 16, 31-50.

Murton, J.B., 2013. Ice wedges and ice wedge casts. In: Elias, S.A., Mock, C.J. (Eds.), Encyclopedia of Quaternary Science. Elsevier, Amsterdam, pp. 436-451.

Payette, S., Séguin, M.K., 1979. Les buttes minérales cryogènes dans les basses terres de la Rivièreaux-Feuilles, Nouveau Québec. Géographie Physique et Quaternaire XXIII, 339-358.

Philip, H., Rogozhin, E., Cisternas, A., Bousquet, J.C., Borisov, B., Karakhanian, A., 1992. The Armenian earthquake of 1988 December 7: faulting and folding, neotectonics and palaeoseismicity. Geophysical Journal International 110, 141-158.

Pissart, A., 2000. Remnants of lithalsas of the Hautes Fagnes, Belgium: a summary of present-day knowledge. Permafrost and Periglacial Processes 11, 327-355. 
Pollard, W.H., 1991. Seasonal frost-mounds. The Canadian Geographer 35, 2014-2018.

345

346

347

348

Radjai, F., Wolf, D.E., Jean, M., Moreau, J.J., 1998. Bimodal Character of Stress Transmission in Granular Packings. Physical Review Letters 80, 61-64.

Ravier, E., Buoncristiani, J.F., Menzies, J., Guiraud, M,. Portier, E., 2015. Clastic injection dynamics during ice front oscillations: a case example from Sólheimajökull (Iceland). Sedimentary Geology 323, 92-109.

Roche, O., van Wyk de Vries, B., Druitt, T.H., 2001. Sub-surface structures and collapse mechanisms of summit pit. Journal of Volcanology and Geothermal Research 105, 1-18.

Sanford, A.R., 1959. Analytical and experimental study of simple geologic structures. Bulletin of the Geological Society of America 70, 19-52.

Siebert, L., 1984. Large volcanic debris avalanches: characteristics of source areas, deposits, and associated eruptions. Journal of Volcanology and Geothermal Research 22, 163-197.

Simón, J.L., Soriano, A., 1986. Diapiric deformations in the Quaternary deposits of the central Ebro Basin, Spain. Geological Magazine 123, 45-57.

Simón, J.L., Soriano, M.A., Pérez, A., Luzón, A., Pocovi, A., Gil H., 2014. Interacting tectonic faulting, karst subsidence, diapirism and continental sedimentation in Pleistocene deposits of the central Ebro Basin (Spain). Geological Magazine 151, 1115-1134.

Soriano, M.A., Luzón, A., Yuste, A., Pocovi, A., Pérez, A., Simón, J.L., Gil H., 2012. Quaternary alluvial sinkholes: record of environmental conditions of karst development, examples from the Ebro Basin, Spain. Journal of Cave and Karst Studies 74, 173-185.

Torabi, A., Braathen, A., Cuisiat, F., Fossen, H., 2007. Shear zones in porous sand: insights from ringshear experiments and naturally deformed sandstones. Tectonophysics 437, 37-50.

Vandenberghe, J., French, H., Gorbunov, A., Marchenko, S., Velichko, A.A., Jin, H., Cui, Z., Zhang, T., Wan, X., 2014. The Last permafrost Maximum (LPM) map of the Northern Hemisphere: permafrost extent and mean annual air temperatures, 25-17 ka. Boreas 43, 652-666.

Van Loon, A.J., Pisarska-Jamrozy, M., 2014. Sedimentological evidence of Pleistocene earthquakes in NW Poland induced by glacio-isostatic rebound. Sedimentary Geology 300, 1-10.

Van Loon, A.J., Pisarska-Jamrozy, M., Nartiss, M., Krievans, M., Soms, J., 2016. Seismites resulting from high-frequency, high-magnitude earthquakes in Latvia caused by Late Glacial glacio-isostatic uplift. Journal of Palaeogeography 5, 360-380. 
Walter, T.R., Troll, V.R., 2001. Formation of caldera periphery faults: an experimental study. Bulletin of Volcanology 63, 191-203.

Yarnold, J.C., 1993. Rock-avalanche characteristics in dry climates and the effect of flow into lakes: insights from mid-Tertiary sedimentary breccias near Artillery Peak, Arizona. Geological Society of America Bulletin 105, 345-360.

Zeeberg, J., 1998. The European sand belt in Eastern Europe and comparison of Late Glacial dune orientation with GCM simulation results. Boreas 27, 127-139.

\section{Figure captions}

Figure 1. (A) Pleistocene sand wedge, Salaunes (SW France), (B) Close up view of the vertical lamination in a sand wedge from La Louverie (Loire valley, France), (C) Sand wedge with apophyses, Saint-Amand-les-Eaux (N France), (D) Globular structure (DSW) caused by the deformation of a sand wedge, Saint-André-de-Cubzac (SW France); the sand wedge (SW) is visible on the bottom of the trench below the dotted line.

Figure 2. (A) Ground thermal contraction polygons, Peissen $\left(X=9.5878^{\circ} \mathrm{E}, \mathrm{Y}=54.0414^{\circ} \mathrm{N}\right)$; (B) Polygons, Beldorf $\left(X=9.3540^{\circ} \mathrm{E}, \mathrm{Y}=54.1213^{\circ} \mathrm{N}\right.$ ) (Google Earth, photos 2009).

Figure 3. Brittle deformation of sandy soil models. (A) Radial fractures and central polygonal depression formed by the rise of a ball under a granular cover, redrawn from Komuro (1987); (B) Fracturing of a sand cover following chamber inflation, from Walter and Troll (2001); (C) Formation of curved reverse faults in sand due to the lifting of a substratum block, from Sanford (1959); (D) Bellshaped reverse faults above a cavity, from Geyer et al. (2006); (E) Annular fracture above a cavity, from Walter and Troll (2001) (the chamber is indicated by the grey dashed line); (F) Deformation after swelling followed by emptying of a chamber, from Walter and Troll (2001); (G) Asymmetric collapse above a cavity in the presence of a relief, from Coumans and Stix (2016); (H) Deformation of a cover as a result of horizontal shortening, from Ballard et al. (1987).

Figure 4. (A) Radial cracks on a pingo (ice-cored mound), Tuktoyaktuk, Canada (Google Earth); (B) Radial and tangential faults around a salt diapir, redrawn from Davison et al. (2000); (C) Reverse faults in Pleistocene thermokarst lake deposits, Gourgançon (Paris Basin, France); (D) Thrust planes at the toe of a landslide, Les Leches (SW France); (E) Bell-shaped reverse faults above a karstic cavity, Mérignac (SW France). 
404 Figure 5. (A, B) Fractured pebbles in the Lower Pleistocene Valensole II Formation, near Sisteron (SE 405 France); the finer-grained material to the left of photo $B$ is a fault gouge; the largest pebble is $10 \mathrm{~cm}$ 406 long; (C) Gelifracted pebble in an active layer above permafrost, Tuktoyaktuk (Canada); (D) 407 Gelifracted sandy limestones, French Pyrenees (France); the largest pebbles are $20 \mathrm{~cm}$ in diameter; 408 (E) Jigsaw structure in the Mont Granier rock avalanche (French Alps); knife for scale; (F) Jigsaw 409 structure in a volcanic rock avalanche, Guadeloupe Island (French West Indies); the section is $1.5 \mathrm{~m}$ 410 high. 


\section{Click here to download high resolution image}
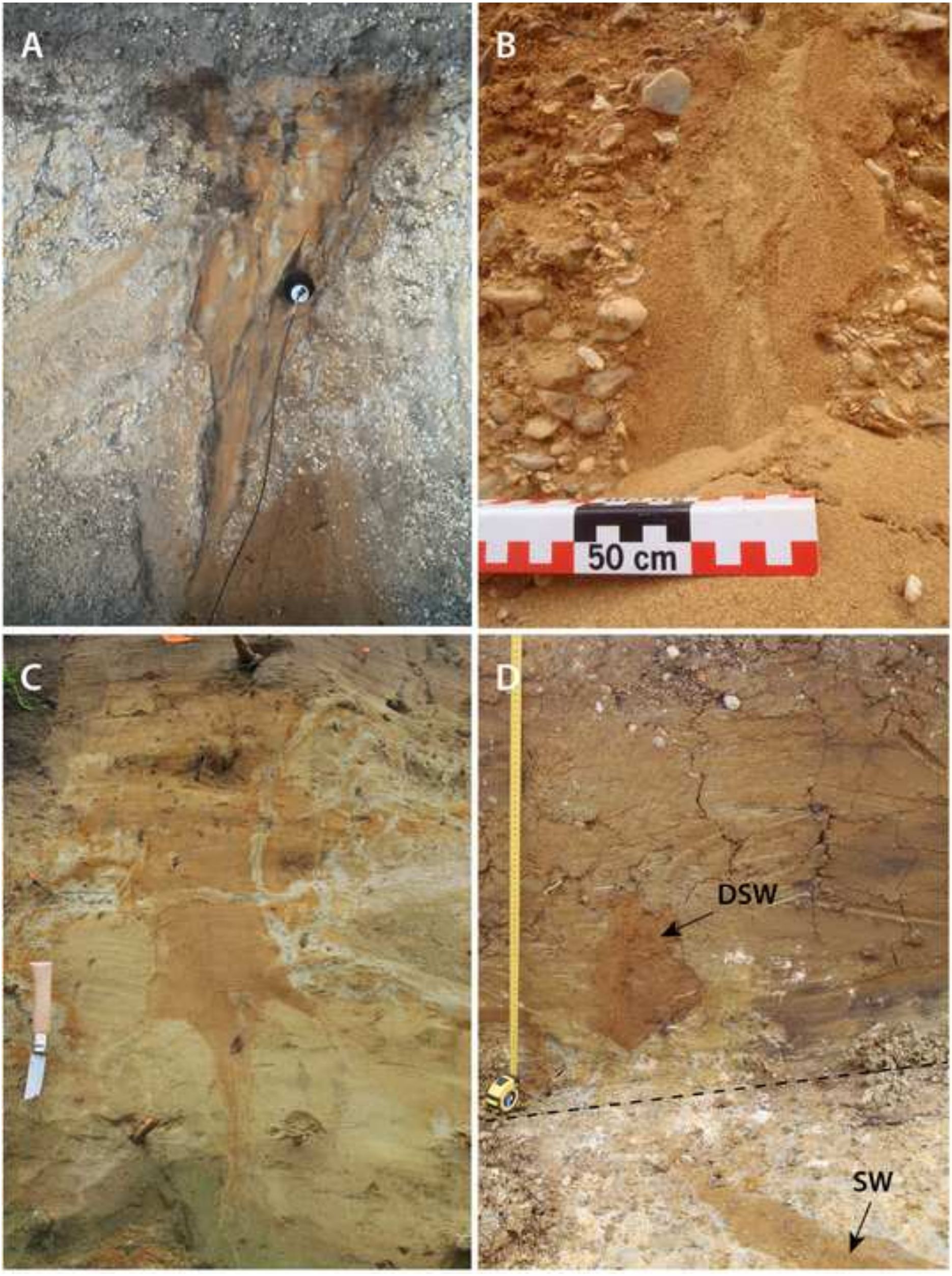


\section{Figure (Color}

Click here to download high resolution image
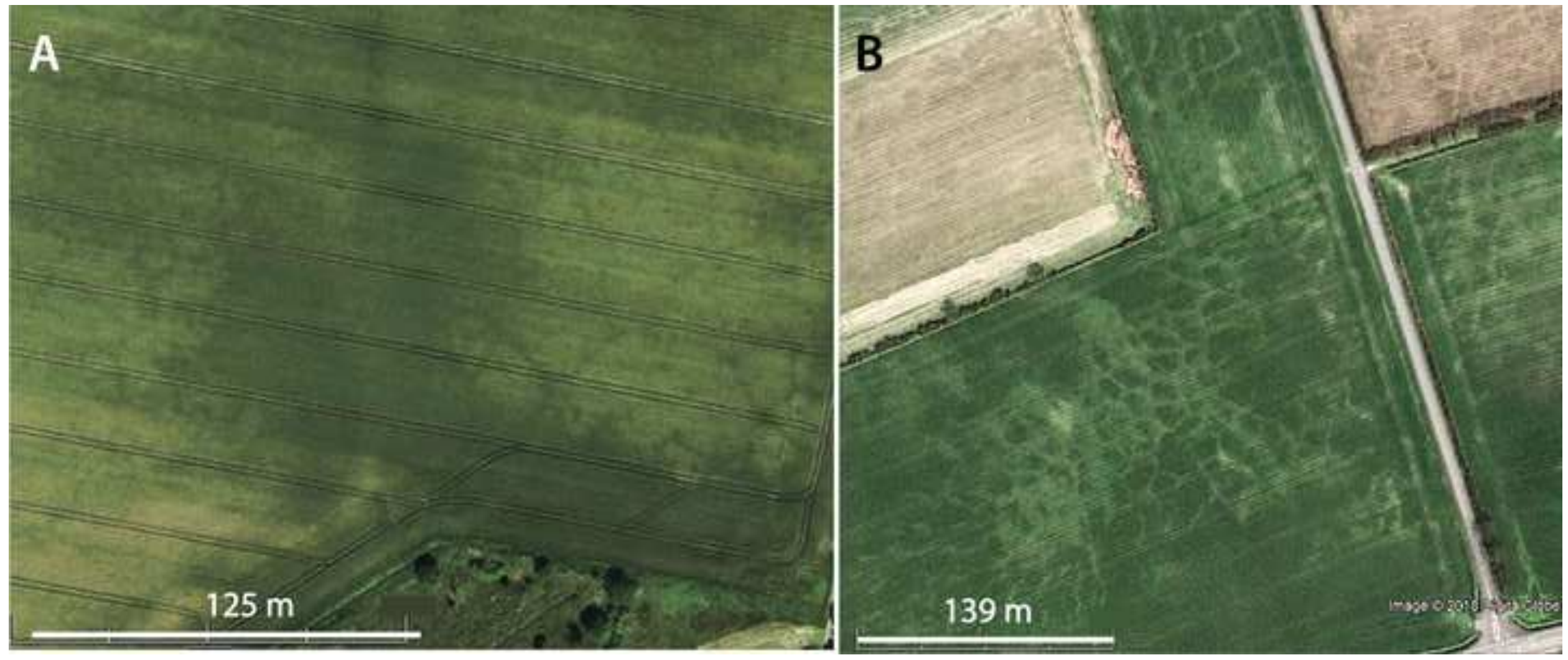
Figure (Color)

Click here to download high resolution image
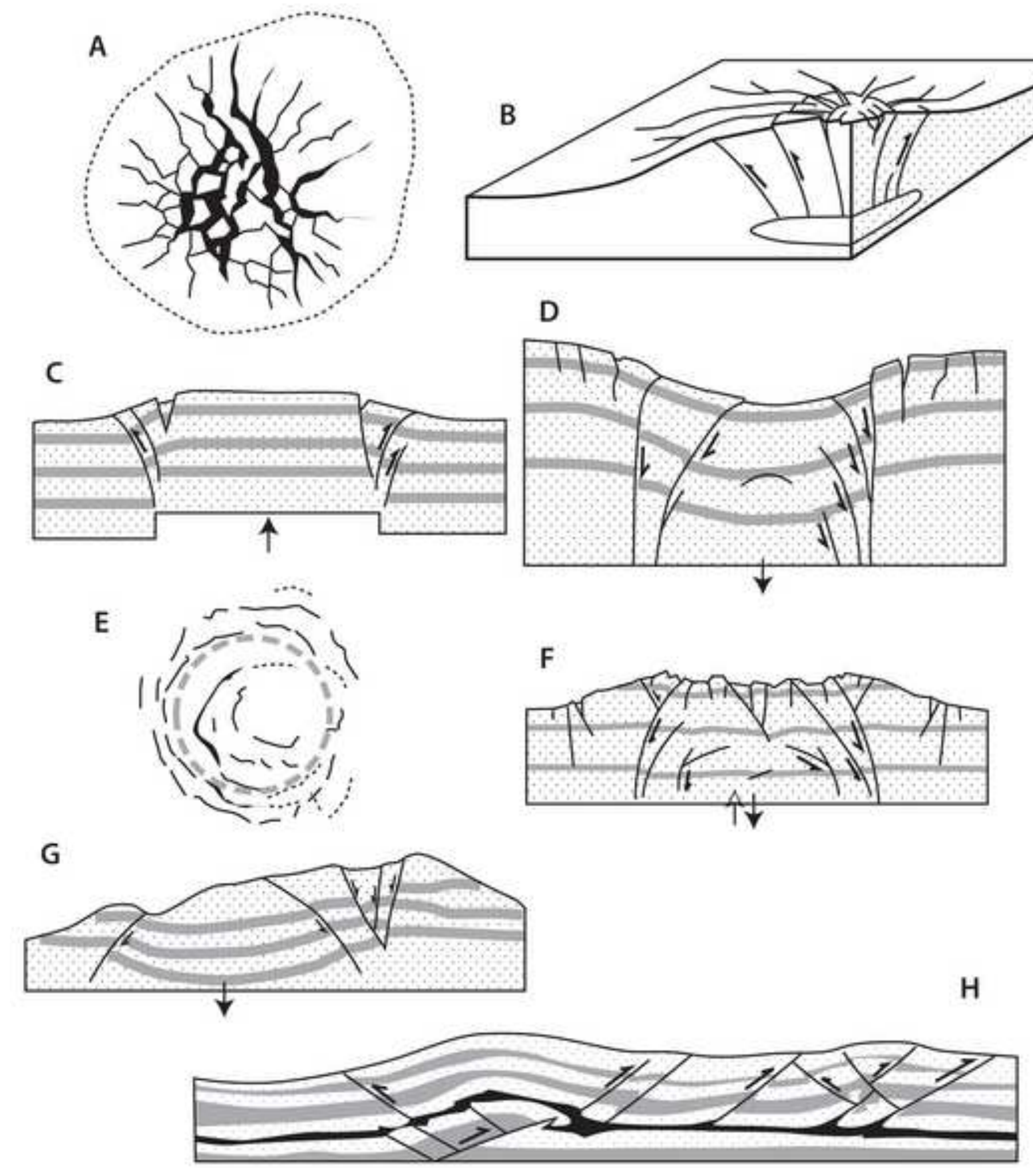

D

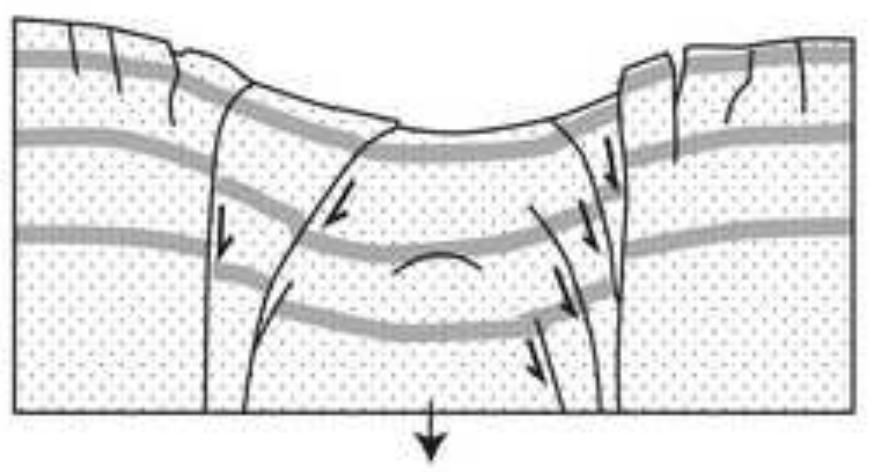


Figure (Color)

Click here to download high resolution image

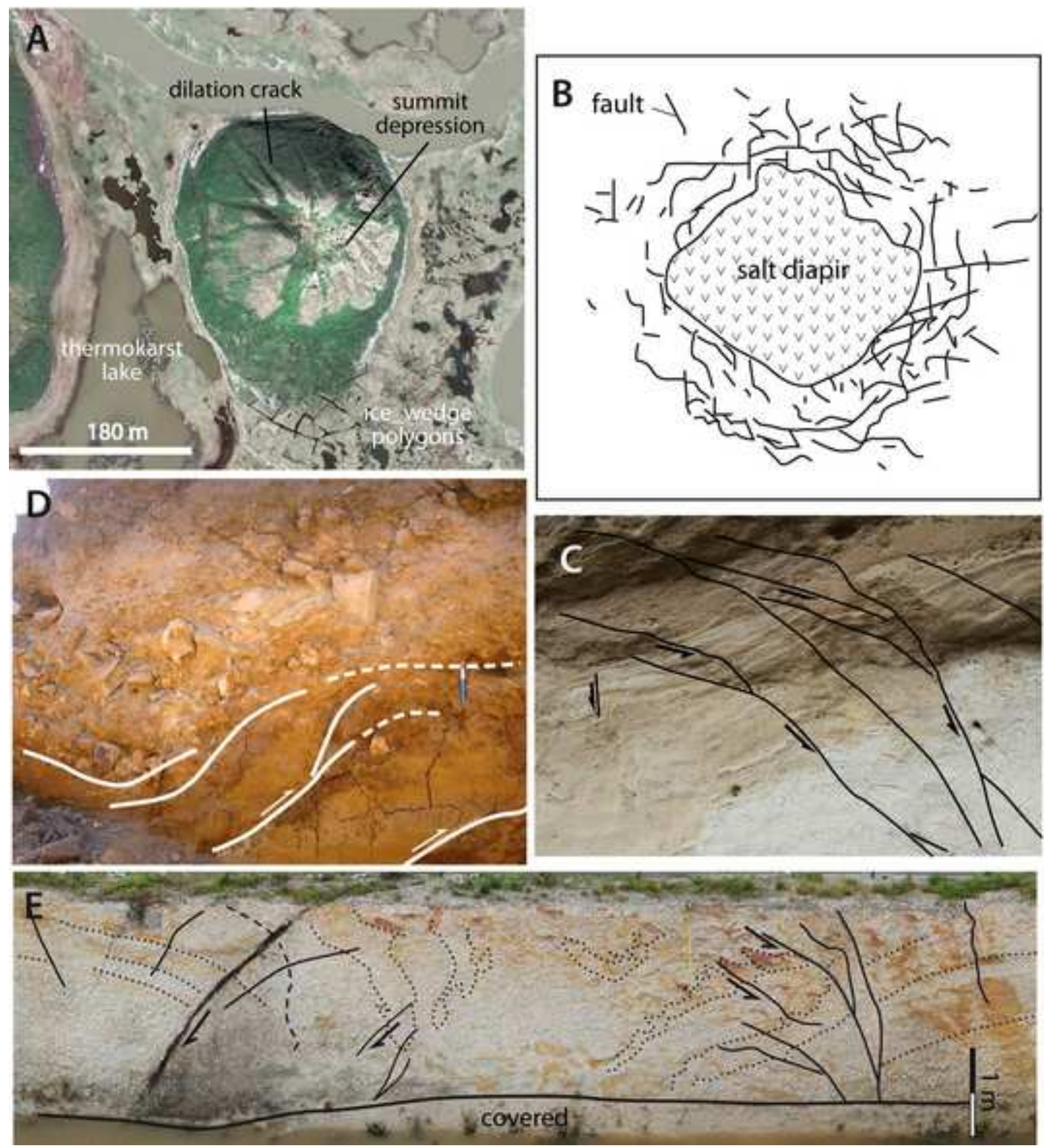



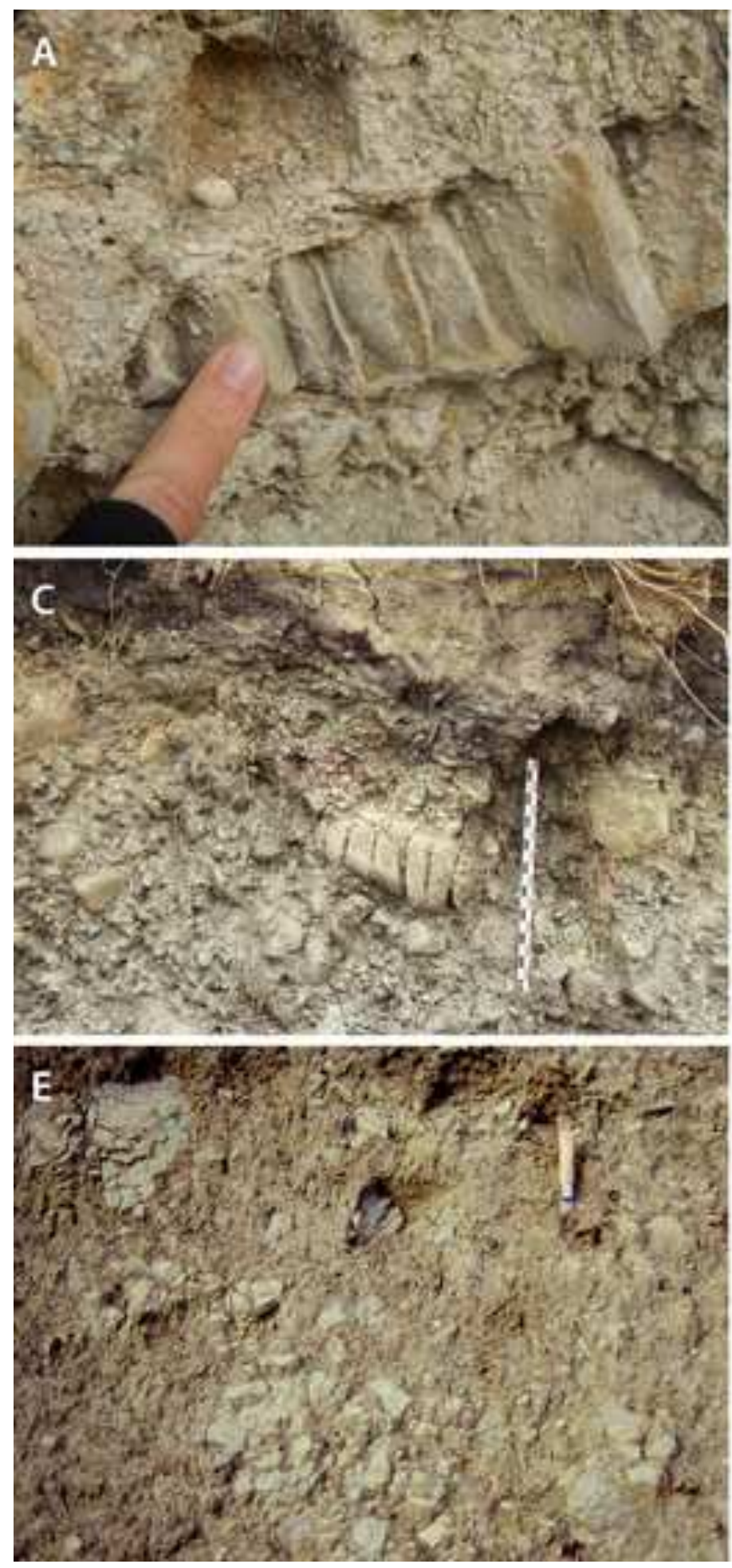
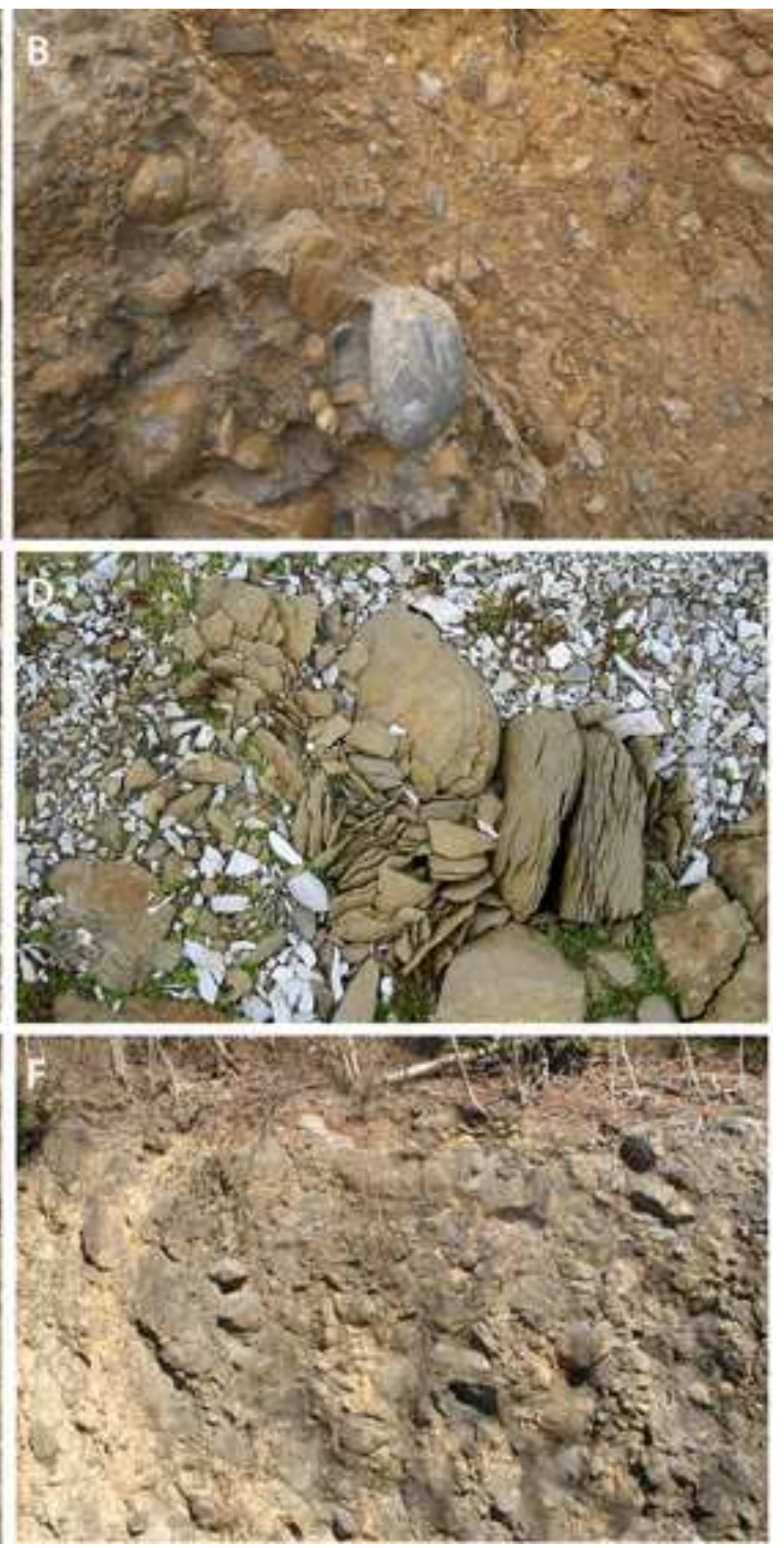